\title{
Ecological assessment of type, abundance and infestation status of invasive alien species (IAS) in eastern part of Ethiopia; suggestion of inventory and monitoring protocols-IAS
}

\begin{abstract}
Background: The type and distribution of IAS in eastern part of Ethiopia become a very serious issue and infested with in a very high speed. The main aim of this assessment is in order to assess the type, current infestation rate, and to estimate the general abundance of IAS in the eastern part of Ethiopia and used to take or plan appropriate measurement methods as well as in the long run it is important for policy makers to take over an immediate action.
\end{abstract}

Methods: Data collection was performed though interview, filed survey, group discussion, and from different formerly published prepares.

Result: From this data we can understand that the infestation stage of IAS, its impact, majorly dominate spices and future projection of those IAS is clearly identified.

Conclusion: The issues need an immediate and fast response before it becomes totally damage the whole native biodiversity resource and also the community leave on that area become both economically, socially and healthy dependence due to the effect of those IAS on the other body.

Keywords: IAS, eastern ethiopia, biodiversity, land cover, type
Volume 3 Issue 5 - 2018

\author{
Yeneayehu Fenetahun, ' Wang Yongdong, ${ }^{2} \mathrm{Xu}$ \\ Xinwen, ${ }^{2}$ Girma Eshetu ${ }^{3}$ \\ 'University of China Academy of Science (UCAS), China \\ ${ }^{2}$ Xinjiang Institutes of Ecology and Geography, China \\ ${ }^{3}$ Ethiopian Biodiversity Institute (EBI), Harar Biodiversity center, \\ Ethiopia
}

Correspondence: Wang Yongdong, Xinjiang Institutes of Ecology and Geography, Chinese Academy of Science, Urumqi Xinjiang, 8300 I I, China, Email wamgyd@ms.xjb.ac.cn

Received: October 25, 2018 | Published: November 28, 2018

\section{Background}

Invasive alien spices (IAS) are one of the most serious threats to ecosystems and economies worldwide. ${ }^{1-3}$ These problematic nonnative species are known to have negative impacts on biodiversity, ecosystem functioning, and an array of other natural processes and human activities. ${ }^{4,5}$ The increasing threat of invasive plants is fueled by a diverse set of fast- and slow-paced human disturbance drivers including climate change, ${ }^{6}$ habitat alteration and fragmentation, intentional introductions,${ }^{8}$ and an increasingly globalized horticulture trade. ${ }^{9}$ Vines (herbaceous and shrubby climbing plants) can prove especially problematic upon establishment in novel areas. This is because of their fast growth rates, which facilitate their ability to out-compete host vegetation by blocking access to light, ultimately reducing host survival and dramatically altering ecosystem structure. Early detection of invasive plants, facilitated through mapping efforts, is critical for rapid response and effective monitoring strategies. ${ }^{10} \mathrm{In}$ Ethiopia, there are more than 22 invasive alien species. ${ }^{11}$ Among these invasive alien species Mesquites (Prosopis juliflora), parthenium weed (Parthenium hysterophorus), water hyacinth (Eichhornia crassipes), Lantana camara, and Acacia species are causing major problems in the country. Although not currently listed as an invasive alien species in Ethiopia, ${ }^{12}$ it potentially poses a major threat to biodiversity and local pastoral livelihoods in different part of the region eastern part of Ethiopia. Ethiopian Biodiversity Institute together with the community and different stakeholders recognize the need for effective control programmes to different part of the country. So in order to plan and implement the appropriate management plan and practice with regarding to IAS the first thing is that the type, abundance and the distribution status should be clearly understood. Therefore, the main aim of this assessment was that in order to assess the type, current infestation rate, and to estimate the general abundance of IAS and future projection of its infestation rate in the eastern part of Ethiopia (Eastern hararghe, western hararghe, Harari region and Ethiopian Somail region) and in order to take or plan appropriate measurement methods and in the long run it is important for policy makers to take over an immediate action.

\section{Materials and methods}

\section{Assessment Data Collection}

The data for this research was collected from the 4 zonal regions from each kebele rank together with the stakeholders both from zone and kebele by using quester, interview, focal group discussion, filed survey and referring former documented data. In this assessment both the farmers, Experts (agricultural, environmental and forest professionals), students, females, aging peoples were included in all area without any number limitation in freely and giving more time to think about it in order to assess the awareness level of the community, to comparison of the understanding level with in different zone and also give the chance for them to exchange knowledge between them.

\section{Data Analysis}

All data were analyzed both in narration and in Access and Excel databases based on the type and the land coverage abundance of IAS. 


\section{Result}

\section{Western Hararghe region}

The above Table 1 and Figure 1 indicates that in western hararghe region the major IAS are Parthenium, striga, Prosopis Juliflora, lantana Camara and other non-identified species are found. And from the figure we can understand that parthenium, striga and Lantana camara are the dominant IAS in the area respectively and among this parthenium is the most infested and dominate IAS.

Table I Type, current infestation status and total area coverage of IAS in hectare in western Hararghe region of eastern Ethiopia

\begin{tabular}{|c|c|c|c|c|c|c|c|c|}
\hline \multirow[b]{2}{*}{ No. } & \multirow[b]{2}{*}{ List of Woreda } & \multirow[b]{2}{*}{$\begin{array}{l}\text { Total area of } \\
\text { Woreda (ha) }\end{array}$} & \multicolumn{5}{|c|}{ Type, and current coverage stage of IAS in each Woreda (Ha) } & \multirow{2}{*}{$\begin{array}{l}\text { Total } \\
\text { area } \\
\text { that } \\
\text { cover } \\
\text { with IAS } \\
\text { (ha) }\end{array}$} \\
\hline & & & $\begin{array}{l}\text { Striga } \\
\text { (Akenche) }\end{array}$ & $\begin{array}{l}\text { Lantana camara } \\
\text { (Yewof kolo) }\end{array}$ & $\begin{array}{l}\text { Prosopis } \\
\text { juliflora } \\
\text { (Yewoyani Zafe) }\end{array}$ & $\begin{array}{l}\text { Parthenium } \\
\text { hysterophorus }\end{array}$ & $\begin{array}{l}\text { Others (not } \\
\text { scientifically } \\
\text { identified) }\end{array}$ & \\
\hline I & Wani & 27,600 & 10.5 & - & - & 20 & & 30.5 \\
\hline 2 & Gmibi bordadi & 93,460 & 7,430 & 675 & 200 & 9,086 & & $|7,39|$ \\
\hline 3 & Boki & 86,940 & 7,150 & 3,775 & - & 2,964 & & 13,889 \\
\hline 4 & Awi Gudina & $3,09,840$ & -- & -- & -- & --- & & --- \\
\hline 5 & Geba Kuricha & 64,220 & 7,430 & 675 & -- & 9,186 & & $|7,29|$ \\
\hline 6 & Ebro & 69,020 & 8,500 & -- & -- & 10,000 & & 18,500 \\
\hline 7 & Beki Intu & $2,56,630$ & -- & --- & --- & ---- & & ---- \\
\hline 8 & Anchar & 98,510 & 525.5 & 285 & --- & 7,650 & & $8,460.50$ \\
\hline 9 & Choki & 58,850 & 1,500 & 930 & -- & 15,597 & 3,195(wonjel) & 21,222 \\
\hline 10 & Hirna & 46,710 & 2,240 & 2,620 & -- & -- & - & 4,860 \\
\hline 11 & Woela & 67,390 & 668 & 500 & --- & 2,575 & & 3,743 \\
\hline 12 & Woda Bultu & $2,37,090$ & 3,258 & 8,500 & --- & 5,810 & & 17,568 \\
\hline 13 & Deba & 77,690 & 35 & ---- & -- & 5,700 & & 5,735 \\
\hline 14 & Gemches & 97,270 & 40 & 100 & --- & 200 & & 340 \\
\hline 15 & Daro lebu & I,31,780 & 5,280 & 2,500 & --- & 15,280 & & 23,050 \\
\hline Total & 15 & $17,23,000$ & 44,067 & 20,560 & 200 & 84,068 & 3,195 & $\begin{array}{l}I 52,090 \\
=8.83 \% \text { of } \\
\text { the total }\end{array}$ \\
\hline
\end{tabular}

Total area of the region is $1,723,000$ hectare and total woreda in the region are 15 .

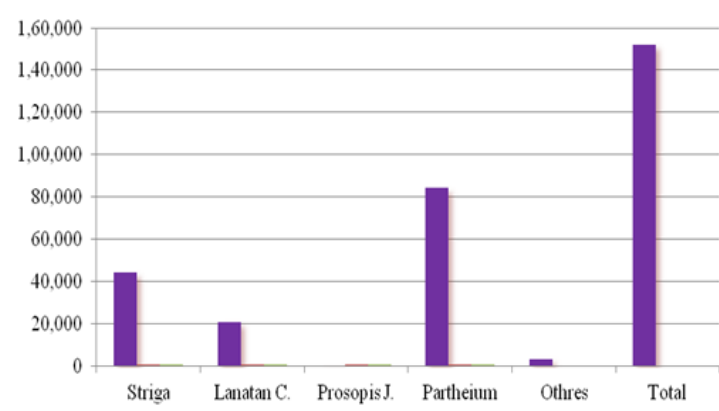

Figure I The total land covers of IAS that is found in western Hararghe zone.

The above Table 2 and Figure 2 indicates that in Eastern hararghe region the major IAS are Parthenium, and lantana Camara and also other non-identified species are found. And from the figure we can understand that Lantana camara is the most dominant IAS in the area followed by Parthenium species.
As we have seen from the above Table 3 and Figure 3 the total area (ha) of each woreda in harari regional state of Ethiopia is not well known yet, as a result it is difficult to get the exact amount of area coverage by IAS from the total area of each region. And such like problem also faced in Ethiopian Somali region. And when we see 
the existence of IAS in the area Parthenium and lantana camara are the most seriously infested species of IAS and it needs fast response from the whole community unless it becomes over dominant and affected the whole area of the region.

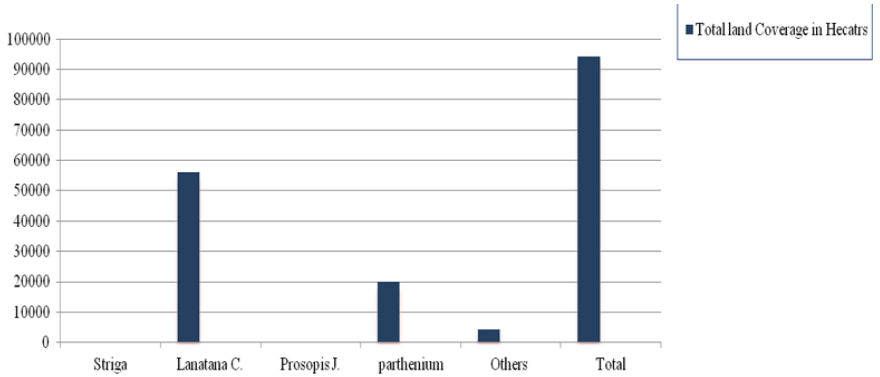

Figure 2 The total land covers of IAS that is found in Eastern Hararghe zone.

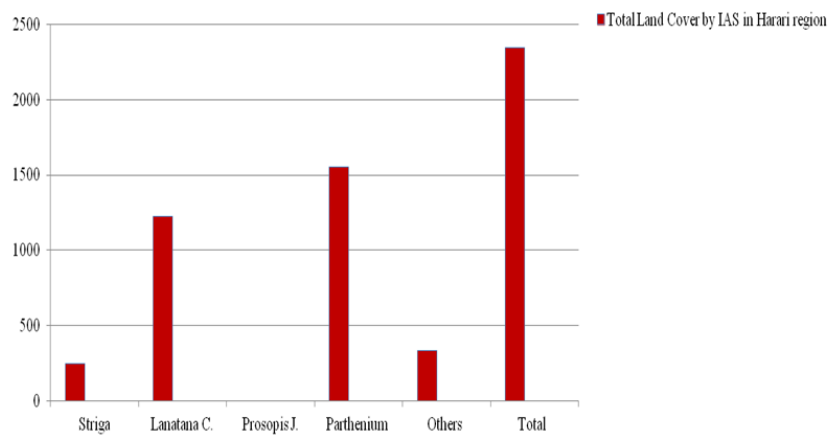

Figure 3 The total land covers of IAS that is found in Harari region.
As I mentioned earlier above in the Ethiopian Somail region the total area of each woreda as well as the total number in hectare that covered by IAS is not recorded yet. And this is one of the basic challenging issues during the data collection and also the implementation of appropriate methods to avoid those IAS that are found within the woreda. So due to this problem I simply try to identify the type of IAS found in each area without the exact number of area coverage. Therefore the above Table 4 and Figure 4 shows that the type of IAS found within the woreda and the total number of woreda's that are affected by those IAS either one or more than one. And from the figure we can understand that Prosopis juliflora is occurred in most woreda and highly affected the existing area followed by Parthenium species.

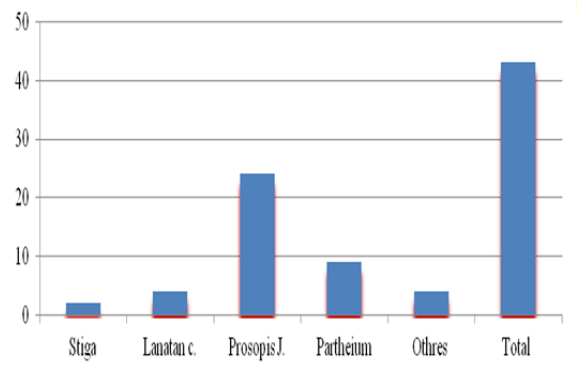

unumber of Woredasthat LAS erist(Not inhectars)

Figure 4 The total number of woreda's that $f$ IAS are found in Ethiopian Somail region (But not in total land cover in hectares')

Note ' $V$ '= indicates the existence of IAS whereas '- 'indicates the absence of IAS

Inventory \& monitoring protocols-invasive alien plants on the existing area

(Table 5)

Table 2 Type, Current infestation status and total area coverage of IAS in hectare in Eastern Hararghe region of Eastern Ethiopia

\begin{tabular}{|c|c|c|c|c|c|c|c|c|}
\hline \multirow[b]{2}{*}{ No. } & \multirow[b]{2}{*}{$\begin{array}{l}\text { List of } \\
\text { Woreda }\end{array}$} & \multirow[b]{2}{*}{$\begin{array}{l}\text { Total area of } \\
\text { Woreda (ha) }\end{array}$} & \multicolumn{5}{|c|}{ Type, and current coverage stage of IAS in each Woreda (Ha) } & \multirow{2}{*}{$\begin{array}{l}\text { Total area } \\
\text { that cover } \\
\text { with IAS } \\
\text { (ha) }\end{array}$} \\
\hline & & & $\begin{array}{l}\text { Striga } \\
\text { (Akenche) }\end{array}$ & $\begin{array}{l}\text { Lantana } \\
\text { camara (Yewof } \\
\text { kolo) }\end{array}$ & $\begin{array}{l}\text { Prosopis } \\
\text { juliflora } \\
\text { (Yewoyani Zafe) }\end{array}$ & $\begin{array}{l}\text { Parthenium } \\
\text { hysterophorus }\end{array}$ & $\begin{array}{l}\text { Others (not } \\
\text { scientifically } \\
\text { identified) }\end{array}$ & \\
\hline I & Babile & $2,07,217$ & 200 & 2,384 & - & 2000 & 192 & 4,584 \\
\hline 2 & Kersa & $46,103.63$ & 106 & -- & - & 2011.5 & - & $2,117.50$ \\
\hline 3 & Gursum & $59,850.17$ & 2801 & -- & 80 & 4300 & - & 7,101 \\
\hline 4 & Bedno & 97,300 & 928 & 610 & - & 783 & - & 2,321 \\
\hline 5 & Meta & 75,397 & 452.5 & 3,900 & - & 1150 & $\mathrm{I}, 024$ & $6,526.50$ \\
\hline 6 & Melka bolo & $|, 39,59|$ & 480 & 4,417 & - & 3450 & 2,787 & II, 134 \\
\hline 7 & Muti & 21,954 & 30 & 1,237 & - & -- & - & $\mathrm{I}, 267$ \\
\hline 8 & Miga tola & 29,453 & 3002 & $|, 8| 2$ & - & -- & - & $4,8 \mid 4$ \\
\hline 9 & Chenagesen & 77,887, & -- & 394 & - & 385 & - & 779 \\
\hline 10 & Fidus & $1,10,502$ & 6250 & $\mathrm{I}, 494$ & - & 540 & - & 8,284 \\
\hline 11 & Haramaya & 55,400 & -- & 18,000 & - & -- & 62 & 18,062 \\
\hline 12 & Deder & 67,428 & -- & 4,693 & - & 1200 & - & 5,893 \\
\hline 13 & Goergultu & 54,123 & -- & 3,665 & - & -- & - & 3,665 \\
\hline 14 & Gerawa & $\mathrm{I}, 10,94 \mathrm{I}$ & -- & -- & - & -- & - & -- \\
\hline 15 & Kurfa chela & $30,345.36$ & -- & 2,905 & - & -- & - & 2,905 \\
\hline
\end{tabular}


Table Continued

\begin{tabular}{|c|c|c|c|c|c|c|c|c|}
\hline \multirow[b]{2}{*}{ No. } & \multirow[b]{2}{*}{$\begin{array}{l}\text { List of } \\
\text { Woreda }\end{array}$} & \multirow[b]{2}{*}{$\begin{array}{l}\text { Total area of } \\
\text { Woreda (ha) }\end{array}$} & \multicolumn{5}{|c|}{ Type, and current coverage stage of IAS in each Woreda $(\mathrm{Ha})$} & \multirow{2}{*}{$\begin{array}{l}\text { Total area } \\
\text { that cover } \\
\text { with IAS } \\
\text { (ha) }\end{array}$} \\
\hline & & & $\begin{array}{l}\text { Striga } \\
\text { (Akenche) }\end{array}$ & $\begin{array}{l}\text { Lantana } \\
\text { camara (Yewof } \\
\text { kolo) }\end{array}$ & $\begin{array}{l}\text { Prosopis } \\
\text { juliflora } \\
\text { (Yewoyani Zafe) }\end{array}$ & $\begin{array}{l}\text { Parthenium } \\
\text { hysterophorus }\end{array}$ & $\begin{array}{l}\text { Others (not } \\
\text { scientifically } \\
\text { identified) }\end{array}$ & \\
\hline 16 & Saremaw & $2,57,687$ & -- & -- & - & -- & - & -- \\
\hline 17 & Kumbi & 29,790 & -- & - & - & -- & - & -- \\
\hline 18 & Goloda & 59,790 & -- & 924 & - & -- & - & 924 \\
\hline 19 & Komebolcha & 46,461 & -- & 9,463 & - & -- & - & 9,463 \\
\hline 20 & Jarso & 51,506 & -- & - & - & -- & - & -- \\
\hline Total & 20 & $16,28,725$ & $14,249.50$ & 55,898 & 80 & $19,819.50$ & 4,065 & $\begin{array}{l}94,032=5.8 \% \\
\text { from the } \\
\text { total }\end{array}$ \\
\hline
\end{tabular}

Total area of the region is $1,628,725$ hectare and total woreda in the region are 20.

Table 3 Type, Current infestation status and total area coverage of IAS in hectare in Harari region of Eastern Ethiopia

\begin{tabular}{|c|c|c|c|c|c|c|c|c|}
\hline \multirow[b]{2}{*}{ No. } & \multirow[b]{2}{*}{$\begin{array}{l}\text { List of } \\
\text { Woreda }\end{array}$} & \multirow[b]{2}{*}{$\begin{array}{l}\text { Total area of } \\
\text { Woreda (ha) }\end{array}$} & \multicolumn{5}{|c|}{ Type, and current coverage stage of IAS in each Woreda (Ha) } & \multirow{2}{*}{$\begin{array}{l}\text { Total area } \\
\text { that cover } \\
\text { with IAS } \\
\text { (ha) }\end{array}$} \\
\hline & & & $\begin{array}{l}\text { Striga } \\
\text { (Akenche) }\end{array}$ & $\begin{array}{l}\text { Lantana } \\
\text { camara (Yewof } \\
\text { kolo) }\end{array}$ & $\begin{array}{l}\text { Prosopis juliflora } \\
\text { (Yewoyani Zafe) }\end{array}$ & $\begin{array}{l}\text { Parthenium } \\
\text { hysterophorus }\end{array}$ & $\begin{array}{l}\text { Others (not } \\
\text { scientifically } \\
\text { identified) }\end{array}$ & \\
\hline I & Sofi & $\begin{array}{l}\text { Not exactly } \\
\text { known }\end{array}$ & 160 & 1040 & - & 1000 & 211 & 1511 \\
\hline 2 & Genila & “ & 10 & 12 & 4.5 & - & - & 26.5 \\
\hline 3 & Abader & “ & & & & - & & \\
\hline 4 & Eror & “ & 81 & 165 & & 424.5 & 126 & 796.5 \\
\hline 5 & Abubeker & “ & & & & - & & \\
\hline 6 & Awohakim & “ & & & & - & & \\
\hline 7 & Aminur & “ & & & & - & & \\
\hline 8 & Shenkor & “" & - & 9 & - & - & - & 9 \\
\hline 9 & Dagiteyara & “ & & & & 129 & & \\
\hline Total & 9 & “ & $25 I$ & 1,226 & 4.5 & I,553.50 & 337 & $\begin{array}{l}2,343=6.83 \% \\
\text { from the } \\
\text { total }\end{array}$ \\
\hline
\end{tabular}

Total area of the region is 34,326 hectare and total woreda in the region are 9 .

Table 4 Type, Current infestation status and total area coverage of IAS in hectare in Ethiopian Somail region of Eastern Ethiopia

\begin{tabular}{|c|c|c|c|c|c|c|c|c|}
\hline \multirow[b]{2}{*}{ No. } & \multirow[b]{2}{*}{$\begin{array}{l}\text { List of } \\
\text { Woreda }\end{array}$} & \multirow[b]{2}{*}{$\begin{array}{l}\text { Total area of } \\
\text { Woreda (ha) }\end{array}$} & \multicolumn{5}{|c|}{ Type, and current coverage stage of IAS in each Woreda (Ha) } & \multirow[b]{2}{*}{$\begin{array}{l}\text { Total area } \\
\text { that cover } \\
\text { with IAS } \\
\text { (ha) }\end{array}$} \\
\hline & & & $\begin{array}{l}\text { Striga } \\
\text { (Akenche) }\end{array}$ & $\begin{array}{l}\text { Lantana } \\
\text { camara } \\
\text { (Yewof kolo) }\end{array}$ & $\begin{array}{l}\text { Prosopis } \\
\text { juliflora } \\
\text { (Yewoyani } \\
\text { Zafe) }\end{array}$ & $\begin{array}{l}\text { Parthenium } \\
\text { hysterophorus }\end{array}$ & $\begin{array}{l}\text { Others (not } \\
\text { scientifically } \\
\text { identified) }\end{array}$ & \\
\hline I & Keberidar & Not well known yet & $\sqrt{ }$ & - & $\sqrt{ }$ & - & - & 2 \\
\hline 2 & Shayesasi & Not well known yet & $\sqrt{ }$ & - & $\sqrt{ }$ & - & - & 2 \\
\hline 3 & Shelayibo & Not well known yet & - & - & $\sqrt{ }$ & - & - & $\mathrm{I}$ \\
\hline 4 & Wareder & Not well known yet & - & - & $\sqrt{ }$ & - & - & I \\
\hline 5 & Danan & Not well known yet & - & - & $\sqrt{ }$ & - & - & $\mathrm{I}$ \\
\hline 6 & Godi & Not well known yet & - & - & $\sqrt{ }$ & - & - & I \\
\hline 7 & Kalafo & Not well known yet & - & - & $\sqrt{ }$ & - & - & I \\
\hline 8 & Mantihali & Not well known yet & - & - & $\sqrt{ }$ & - & - & 1 \\
\hline 9 & Babile & Not well known yet & - & $\sqrt{ }$ & - & $\sqrt{ }$ & - & 2 \\
\hline 10 & Ferefer & Not well known yet & - & - & $\sqrt{ }$ & - & - & I \\
\hline
\end{tabular}


Table Continued

\begin{tabular}{|c|c|c|c|c|c|c|c|c|}
\hline \multirow[b]{2}{*}{ No. } & \multirow[b]{2}{*}{$\begin{array}{l}\text { List of } \\
\text { Woreda }\end{array}$} & \multirow[b]{2}{*}{$\begin{array}{l}\text { Total area of } \\
\text { Woreda (ha) }\end{array}$} & \multicolumn{5}{|c|}{ Type, and current coverage stage of IAS in each Woreda (Ha) } & \multirow[b]{2}{*}{$\begin{array}{l}\text { Total area } \\
\text { that cover } \\
\text { with IAS } \\
\text { (ha) }\end{array}$} \\
\hline & & & $\begin{array}{l}\text { Striga } \\
\text { (Akenche) }\end{array}$ & $\begin{array}{l}\text { Lantana } \\
\text { camara } \\
\text { (Yewof kolo) }\end{array}$ & $\begin{array}{l}\text { Prosopis } \\
\text { juliflora } \\
\text { (Yewoyani } \\
\text { Zafe) }\end{array}$ & $\begin{array}{l}\text { Parthenium } \\
\text { hysterophorus }\end{array}$ & $\begin{array}{l}\text { Others (not } \\
\text { scientifically } \\
\text { identified) }\end{array}$ & \\
\hline II & Doload & Not well known yet & - & - & $\sqrt{ }$ & - & - & I \\
\hline 12 & Emyegalebed & Not well known yet & - & - & $\sqrt{ }$ & - & - & I \\
\hline 13 & Ayadel & Not well known yet & - & - & $\sqrt{ }$ & - & - & I \\
\hline 14 & Shenliye & Not well known yet & - & - & $\sqrt{ }$ & - & - & I \\
\hline 15 & Hadagaile & Not well known yet & - & - & $\sqrt{ }$ & - & - & I \\
\hline 16 & Denbel & Not well known yet & - & - & $\sqrt{ }$ & - & - & I \\
\hline 17 & Ayesha & Not well known yet & - & - & $\sqrt{ }$ & - & - & I \\
\hline 18 & Afedam & Not well known yet & - & - & $\sqrt{ }$ & - & - & I \\
\hline 19 & Beki & Not well known yet & - & - & $\sqrt{ }$ & - & - & I \\
\hline 20 & Megi & Not well known yet & - & - & $\sqrt{ }$ & - & - & I \\
\hline 21 & Eror & Not well known yet & -- & $\sqrt{ }$ & - & $\sqrt{ }$ & - & 2 \\
\hline 22 & Jigjiga & Not well known yet & - & $\sqrt{ }$ & - & - & $\sqrt{ }$ & 2 \\
\hline 23 & Tahilgadi & Not well known yet & - & - & - & $\sqrt{ }$ & - & 1 \\
\hline 24 & Kebrbya & Not well known yet & - & - & - & $\sqrt{ }$ & - & I \\
\hline 25 & Gursum & Not well known yet & - & $\sqrt{ }$ & - & - & $\sqrt{ }$ & 2 \\
\hline 26 & Haroroyes & Not well known yet & - & - & - & $\sqrt{ }$ & - & I \\
\hline 27 & Togowechalie & Not well known yet & - & - & - & $\sqrt{ }$ & - & I \\
\hline 28 & Awobrie & Not well known yet & - & - & - & $\sqrt{ }$ & - & I \\
\hline 29 & Hararo & Not well known yet & - & - & - & $\sqrt{ }$ & - & 1 \\
\hline 30 & Dehabure & Not well known yet & - & - & $\sqrt{ }$ & - & $\sqrt{ }$ & 2 \\
\hline 31 & Berkot & Not well known yet & - & - & $\sqrt{ }$ & - & $\sqrt{ }$ & 2 \\
\hline 32 & Warder & Not well known yet & - & - & - & $\sqrt{ }$ & - & I \\
\hline 33 & Denbel & Not well known yet & - & - & $\sqrt{ }$ & - & - & I \\
\hline 34 & Ayesha & Not well known yet & - & - & $\sqrt{ }$ & - & - & I \\
\hline 35 & Hodagala & Not well known yet & - & - & $\sqrt{ }$ & - & - & I \\
\hline Total & 35 & Not well known yet & 2 & 4 & 24 & 9 & 4 & 43 \\
\hline
\end{tabular}

Total area of the region is $3,500,000$ hectare and total woerda in the region are 35 (Currently there is no the exact data, but this are the major area)

Table 5

\begin{tabular}{|c|c|c|c|}
\hline Survey Level & Questions & Methods & Products \\
\hline $\begin{array}{l}\text { I.Preliminary } \\
\text { (office-oriented) }\end{array}$ & $\begin{array}{l}\text {-What invasive alien plant taxa are } \\
\text { known to occur in the unit? } \\
\text {-What plant communities at the unit are } \\
\text { known to be Invaded by invasive alien } \\
\text { plants? }\end{array}$ & $\begin{array}{l}\text {-Conduct literature and database searches } \\
\text {-Consult with knowledgeable persons and } \\
\text { agencies } \\
\text {-Review any existing documents for the site } \\
\text {-Visit herbaria }\end{array}$ & $\begin{array}{l}\text {-A list of invasive alien plant taxa that } \\
\text { have been documented in the unit } \\
\text { from past site visits or Studies. }\end{array}$ \\
\hline $\begin{array}{l}\text { 2.Reconnaissance } \\
\text { (field-oriented) }\end{array}$ & $\begin{array}{l}\text {-What invasive alien plant occurrences } \\
\text { exist at the unit? }\end{array}$ & $\begin{array}{l}\text {-Walk-through, drive-by, fly-over, and look at } \\
\text { photos of the site } \\
\text {-Create a list of invasive plant taxa observed } \\
\text { during site visits for help with identification } \\
\text { of some invasive taxa and eradication } \\
\text { techniques). } \\
\text { - Have experts verify taxa in question. } \\
\text {-Take general photos }\end{array}$ & $\begin{array}{l}\text {-Products of the Preliminary Level plus: } \\
\text {-A list of invasive alien plant taxa } \\
\text { observed at the site during site visits } \\
\text { - Completed annual inspection \& } \\
\text { questionnaire } \\
\text {-Rapid assessment of invasive alien } \\
\text { plant occurrences }\end{array}$ \\
\hline
\end{tabular}


Table Continued

\begin{tabular}{|c|c|c|c|}
\hline Survey Level & Questions & Methods & Products \\
\hline $\begin{array}{l}\text { 3. Baseline (field- } \\
\text { oriented) }\end{array}$ & $\begin{array}{l}\text {-Where are the invasive alien plant } \\
\text { occurrences located in the unit? } \\
\text {-Is the invasive alien plant occurrence } \\
\text { new or absent compared to previous } \\
\text { years? } \\
\text { - Is there an apparent change in the } \\
\text { taxon or its habitat at the site of the } \\
\text { occurrence compared to previous years? } \\
\text {-What is the areal extent of the invasive } \\
\text { alien plant occurrences in the unit? } \\
\text {-What is the change in areal extent of } \\
\text { the invasive alienplant occurrences }\end{array}$ & $\begin{array}{l}\text {-Methods outlined in the Preliminary Level } \\
\text { plus: } \\
\text {-Visit the unit with aerial photographs and } \\
\text { topographic maps and systematically search } \\
\text { the suitable habitat on foot during the } \\
\text { appropriate blooming period (for taxa that } \\
\text { must be blooming for proper identification). } \\
\text { - Establish photo stations, make general } \\
\text { observations of the site, and note associated } \\
\text { taxa. } \\
\text {-Use the Sawyer-Keeler-Wolf plant } \\
\text { communities Classification system to identify } \\
\text { plant at the unit where invasive alien plant } \\
\text { taxa are observed. } \\
\text {-Use a Global Positioning System (GPS) } \\
\text { unit to create a map of plant taxa locations } \\
\text { as points in GIS. Map and number each } \\
\text { occurrence. } \\
\text {-Outline the surveyed area by hand onto a } \\
\text { topographic map. } \\
\text { Methods outlined in the Preliminary Level } \\
\text { plus: } \\
\text {-Map the stand or population perimeters } \\
\text { as polygons using a GPS unit (some stands } \\
\text { of larger taxa may be mapped using digital } \\
\text { imagery in ArcView or Arclnfo). } \\
\text {-Map entire area surveyed on a topographic } \\
\text { map or GIS map, or by using digital imagery } \\
\text { in ArcView or Arclnfo. } \\
\text {-Create a GIS map using the ArcView or } \\
\text { Arclnfo software. } \\
\text {-Repeat the above periodically and compare } \\
\text { results to previous years (Monitoring). }\end{array}$ & $\begin{array}{l}\text {-comprehensive list of the invasive } \\
\text { alien plant taxa occurrences at the unit } \\
\text { and the associated taxa. } \\
\text {-A comprehensive list of the plant } \\
\text { communities at the unit where invasive } \\
\text { alien plant taxa occurrences exist. } \\
\text {-GIS map with invasive alien plant taxa } \\
\text { locations at the unit mapped as points } \\
\text { or polygons. } \\
\text { - A map of the surveyed area. } \\
\text {-Photos of taxa and/or populations } \\
\text {-Products of the Preliminary Level plus: } \\
\text {-GIS map of invasive alien plant } \\
\text { occurrences and the entire area } \\
\text { surveyed. } \\
\text {-Calculation of acreage of each } \\
\text { occurrence or of all occurrences of a } \\
\text { particular taxon using GIS }\end{array}$ \\
\hline $\begin{array}{l}\text { 4.Comprehensive } \\
\text { (field oriented) }\end{array}$ & $\begin{array}{l}\text {-How many individuals of the invasive } \\
\text { alien taxon are present in each } \\
\text { occurrence? } \\
\text { - What is the phenology of the taxon, } \\
\text { and condition of individuals in the } \\
\text { occurrence? } \\
\text {-What is the species composition or } \\
\text { richness, dominant taxa, condition of } \\
\text { habitat, percent cover by species, relative } \\
\text { abundance, height classes, distribution of } \\
\text { the taxa, }\end{array}$ & $\begin{array}{l}\text { Methods outlined in the Preliminary Level } \\
\text { plus: } \\
\text {-Establish transects and/or quadrats to } \\
\text { collect data on numbers, phenology, disease, } \\
\text { predation, mortality, etc., } \\
\text {-Establish transects and/or quadrats to } \\
\text { collect data on \%cover, relative abundance, } \\
\text { recruitment, height classes, mortality or } \\
\text { disease. }\end{array}$ & $\begin{array}{l}\text { Products of the Preliminary Level plus: } \\
\text { - Data on abundance, frequency, } \\
\text { density, richness, cover, condition of } \\
\text { occurrence and habitat, mortality, etc. } \\
\text {-Detect changes and trends in the } \\
\text { above. } \\
\text {-Map of transect and quadrat locations }\end{array}$ \\
\hline $\begin{array}{l}\text { 5. Intensive (field } \\
\text { and laboratory } \\
\text { oriented) }\end{array}$ & $\begin{array}{l}\text {-Questions related to demographics, } \\
\text { genetics, energy/nutrient cycling, } \\
\text { pollination biology, etc. } \\
\text {-How are the population demographics } \\
\text { or other attributes changing? }\end{array}$ & $\begin{array}{l}\text {-Methods will be dependent upon the nature } \\
\text { of the question and the taxon. Standard } \\
\text { protocols, when available and applicable, } \\
\text { should be employed. } \\
\text {-Repeat the above periodically and compare } \\
\text { results to previous years (Monitoring). }\end{array}$ & $\begin{array}{l}\text {-Detailed and intensive studies and } \\
\text { reports on an attribute of interest with } \\
\text { regard to an invasive alien plant taxon } \\
\text { or occurrence specifically. } \\
\text { - Detect changes and trends. }\end{array}$ \\
\hline
\end{tabular}

\section{Conclusion}

In general the diversity and infestation rate of IAS in Ethiopia is much diversified and rapidly invaded any type of area and affect the biodiversity resource and economically, socially, healthy impact is very crucial issue. And The eastern Part of Ethiopia is one of the most affected area as compared to other part of the country and since most of the community are pastoral and agro-pastoral this IAS infested the area and the communal range land become totally useless and covered by those IAS. From the above data we can understand that almost each woreda was affected by one or more type of IAS and it covered very large amount of the woreda land and reached very high stage of dominance over the native biodiversity resource. So this issue needs the participation of every community and stake holders including the higher officials and take appropriate management techniques at least to keep as it is, unless within few years all of the eastern part of the country land covered by IAS. Finally, we highly recommend as it is not time to keep silent and everybody should be take an action and also the issue included within the education curriculum of the country and more awareness creation should be done before we lose our native biodiversity resource and before we become totally infected both economically, socially, and our health system. And finally I would like 
to recommend all the community as well as stakeholders to identify and understand the full features of IAS to use the above inventory and monitoring methods and easily identify the species from native flora.

\section{Acknowledgments}

We thank both the local community and stakeholders of each zone and woreda for their viable support and provide appropriate evidence.

\section{Funding}

This study was supported by Science and Technology partnership program, Ministry of Science and Technology of China (KY201702010); China-Africa joint research center project of the Chinese academy of Science (SAJC201610).

\section{Availability of data and materials}

The datasets generated during and/or analyzed during the current study are available from the corresponding author on reasonable request.

\section{Authors' contributions}

Yeneayehu Fenetahun and Girma Eshetu designed the study and collection the data and write the initial draft, Xu Xinwen and Wang Yongdong, edit and approved the final work. All authors read and approved the final manuscript.

\section{Competing interests}

The authors declare that they have no competing interests.

\section{References}

1. International Union for Conservation of Nature. IUCN Guidelines for the Prevention of Biodiversity Loss caused by Alien Invasive Species. Information Paper from the Fifth Meeting of the Conference of the Parties to the Convention on Biological Diversity. 51st Meeting of Council, Swizerland: Gland; 2000.
2. Pimentel D, Zuniga R, Morrison D. Update on the environmental and economic costs associated with alien-invasive species in the United States. Ecological Economics. 2005;52(3):273-288.

3. Vilà $M$, Basnou $C$, Pyšek $M$, et al. How well do we understand the impacts of alien species on ecosystem services? A pan-European, cross-taxa assessment. Frontiers in Ecology and the Environment. 2009;8:135-144.

4. Vitousek PM. Biological invasions and ecosystem processes: towards an integration of population biology and ecosystem studies. Oikos. 1990;57:7-13.

5. Hejda M, Pyšek P, Jarošík V. Impacts of invasive plants on the species richness, diversity and the composition of invaded communities. Journal of Ecology. 2009;97(3):393-403.

6. Thuiller W, Richardson DM, Midgley GF. Will climate change promote alien plant invasions? Biological invasions. 2007;193:197-211.

7. With KA. Assessing the risk of invasive spread in fragmented landscapes. Risk Anal. 2004;24(4):803-815.

8. Mack RN, Erneberg M. The United States naturalized flora: largely the product of deliberate introductions. Annals of the Missouri Botanical Garden. 2002;89:176-189.

9. Bradley BA, Blumenthal DM, Early R, et al. Global change, global trade, and the next wave of plant invasions. Frontiers in Ecology and the Environment 2011;10(1):20-28.

10. Kaplan H, van Niekerk A, Le Roux JJ, et al. Incorporating risk mapping at multiple spatial scales into eradication management plans. Biological Invasions. 2014;16(3):691-703.

11. McFadyen RE, Harvey GJ. Distribution and control of rubber vine, Cryptostegia grandiflora, a major weed in northern Queensland. Plant Protection Quarterly. 1990;5(4):152-155.

12. Invasive Species Compendium. Cryptostegia grandiflora datasheet. Invasive Species Compendium, UK: Wallingford; 2014. 